\title{
1. History and theoretical foundations of traditional BTAs
}

This chapter discusses the historical development of BTAs against the background of the removal of tariffs, from Ricardo's economic theory on free trade to more recent views expressed at the political level since the middle of the 20th century.

Although Ricardo's theory on comparative advantage is at the heart of BTAs' rationale, later discussions on BTAs have not always given due credit to BTAs' historical development. The two main official reports on BTAs - the OECD 1968 and GATT 1970 reports - illustrate how national and regional practices vary between countries. These two reports - issued following the US claim that BTAs may not be economically sound - also highlight the main controversies as to BTAs' theoretical grounds in the 1970s. More than 40 years later, controversies remain, adding up to the uncertainties and questions surrounding BTAs' legal framework. The analysis of BTAs' negotiating history contributes to provide a better understanding of WTO law provisions surrounding their adoption. Indeed, the legal limits to the adoption of BTAs very much translate the original objectives that BTAs were intended to pursue. Moreover, BTAs' negotiating history can be used to clarify BTAs' legal framework as one 'supplementary means of interpretation' recognised by the Vienna Convention. ${ }^{1}$

This chapter first analyses BTAs' economic foundation (Section 1.1). Second, BTAs' political history is discussed (Section 1.2). Finally, this chapter offers an overview of BTAs' main theoretical foundations (Section 1.3).

1 See Articles $31 \S 1 \& 32$ of UN Vienna Convention on the Law of Treaties, Vienna, 23 May 1969, UN Treaty Series (1980), Vol. 1155, 1-18232, 332. On the role of the legislative history in interpreting WTO law, see Felicity Deane, Emissions Trading and WTO Law. A Global Analysis (Edward Elgar Publishing 2015), 56-57; Asif H. Qureshi, Interpreting WTO Agreements (CUP 2015), 52-54; Isabelle Van Damme, Treaty Interpretation by the WTO Appellate Body (OUP 2009), 309-320 (on the role of the negotiating history in the interpretation of WTO law). 


\subsection{BTAs' ECONOMIC FOUNDATION}

\subsubsection{BTAs' Historical Development in Light of the History of Tariffs}

The oldest taxes imposed on imported products are tariffs, i.e. taxes imposed on imported products for the simple reason that they have entered the national territory. Though the exact origin of tariffs is difficult to locate, Asakura considers that the world history of customs duties started in ancient times. ${ }^{2}$ In his book on the World History of the Customs and Tariffs, he writes: 'Since the Customs is one of the oldest fiscal mechanisms, it would seem reasonable to assume that the Customs also originated in these cradles of human civilization.'3

Over the years a variety of objectives were pursued by means of tariffs and tariff policy instruments, from discouraging the import of certain goods to providing protection to merchants in exchange for payment. ${ }^{4}$ In the 13th century some cities mutually agreed to remove the tariffs imposed across their respective borders, practically forming the first free trade areas of the time..$^{5}$ Reduced tariffs on imports were also adopted in favour of imported products that were lacking in the domestic economy. ${ }^{6}$

In the 18th century economists started to criticise mercantilism, proposing alternative trade models. Adam Smith, David Ricardo and John Stuart Mill - who are among the most famous economists of the time introduced free trade theories to improve welfare among nations. Under these new economic theories, customs duties became barriers to free trade. Roughly speaking, under free trade theories, tariffs could no longer serve to control international trade. Consequently, countries sometimes linked the removal of tariffs to regulatory prerequisites in order to prevent the import of undesirable products. ${ }^{7}$ For example, the 1935 International Convention concerning the Export and Import of Animal

2 Hironori Asakura, World History of the Customs and Tariffs (WCO 2003), 24.

3 Ibid., 20.

4 Ibid., 19.

5 Ferdinand H.M. Grapperhaus, Tax Tales From the Second Millennium (IBFD 2009), 15. Asakura notes that preferential tariff rates already existed as early as the 10th century under the Byzantine Empire (see Asakura, supra n. 2, $115)$.

Grapperhaus, supra n. 5, 15 \& 19.

7 See Steve Charnovitz, 'The North American Free Trade Agreement: Green Law or Green Spin?' (1994-1995) 26 Law \& Policy in International Business 1, 60-61. 
Products (other than meat, meat preparations, fresh animal products, milk and milk products) limited the free traffic in certain animal products to countries that have ratified the International Convention for the Campaign against Contagious Diseases of Animals. ${ }^{8}$ This example illustrates that the removal of tariffs has been linked to regulatory requirements to guarantee that free trade policies do not conflict with other policy objectives, such as health policies, sanitary measures or environmental protection.

In other words, the call of free trade theorists did not necessarily amount to fully free and unrestricted international trade with a complete removal of barriers (including tax barriers) on imported products. This call rather introduced a distinction between undesirable barriers imposed on imported products (e.g. tariffs) and desirable measures (e.g. some regulatory barriers that are deemed necessary for health reasons) imposed on imported products. BTAs are another example of desirable measures imposed on imported products that have been approved by some free trade theorists. Ricardo argued that tax measures that raise domestic products' prices should also be imposed on imported products. This mechanism - latter called BTAs on imports - is supposed to level the playing field between domestic and foreign products, not to raise tariff barriers against foreign products.

In the middle of the 20th century, states gathered to negotiate a multilateral trade agreement that would provide for general rules to limit the adoption of tariffs. The General Agreement on Tariffs and Trade (GATT) was adopted in 1947 after the first round of tariff negotiations in Geneva. Rapidly, the GATT became the 'international trade treaty'. 9

The GATT translated into formal legal rules the idea that the adoption of tariffs should be limited and strictly regulated to foster free trade. Primarily, WTO law requires member states to bind their tariffs at reduced levels, which means that they accept not raising their tariffs over the bound levels they have committed to. WTO law also requires that the most favourable treatment be applied to all member states, meaning that all WTO members should benefit from the advantages that are granted to another WTO member. This general requirement is called the 'mostfavoured-nation principle' (MFN). ${ }^{10}$

8 Ibid., 60-61, referring to Art. 1, International Convention concerning the Export and Import of Animal Products (other than meat, meat preparations, fresh animal products, milk and milk products), Geneva, 20 February 1935.

9 Jennifer E. Farrell, The Interface of International Trade Law and Taxation (26 IBFD Doctoral Series 2013).

10 GATT Art. 1. 
Despite the general WTO objective of reducing barriers to trade among all member states, WTO law recognises the possibility of maintaining (or adopting) certain taxes (or trade measures) on imported products in order to achieve objectives that do not directly (or primarily) relate to free trade. BTAs are one of these examples.

\subsubsection{The Origin of BTAs' Economic Rationale}

In contrast to tariffs, WTO law does not encourage member states to remove their BTAs. The reason is that BTAs are based on a different rationale than tariffs. BTAs are not imposed on imported products for the simple reason that national borders are crossed. BTAs rather aim to guarantee that the tax treatment that applies to domestic products is neutral vis-à-vis internationally traded goods, meaning imported and exported products.

The economic underpinning for BTAs is generally attributed to David Ricardo. ${ }^{11}$ According to Ricardo, 'just competition' requires that imported products are taxed the same way as domestic products and that a drawback of the same amount as domestic taxes is allowed on exported products. ${ }^{12}$ In his book entitled On Protection to Agriculture, Ricardo explains:

11 Paul Demaret \& Raoul Stewardson, 'Border Tax Adjustments under GATT and EC Law and General Implications for Environmental Taxes' (1994) 28(4) Journal of World Trade 6; Gary Clyde Hufbauer, Fundamental Tax Reform and Border Tax Adjustments (Institute for International Economics 1996), 21-23; Robert Ireland, 'Implications for Customs of Climate Change Mitigation and Adaptation Policy Options: A Preliminary Examination' (2010) 4(2) World Customs Journal 21, 25; John Snape \& Jeremy de Souza, Environmental Taxation Law, Policy, Contexts and Practice (Ashgate Publishing 2006), 9; Terence P. Stewart, Eric P. Salonen \& Patrick J. McDonough, 'More than 50 Years of Trade Rule Discrimination on Taxation: How Trade with China is Affected' (2007) Trade Lawyers Advisory Group, 24. See also OECD, Environment Policy Committee and Committee on Fiscal Affairs. Joint Sessions on Taxation and Environment. 2nd Session. Environmental Taxes and Border Tax Adjustments, COM/ENV/EPOC/DAFFE/CFA(94)31, 27 April 1994, 5, para. 9 (hereafter, 'OECD 1994 note on Environmental BTAs, COM/ENV/EPOC/ DAFFE/CFA(94)31') and the Zenith Case (US Supreme Court, Zenith Radio Corporation v. United States, 437 US 443 (1978)), where a direct reference was made to David Ricardo.

12 David Ricardo, The Works and Correspondence of David Ricardo (Pamphlets and Papers 1815-1823, ed. Piero Sraffa with the Collaboration of M.H. Dobb, Liberty Fund 2005, Vol. 4), available at <http://oll.libertyfund.org/ title/205/38614/885295> (accessed 21 January 2014). 
A tax ... which falls exclusively on the producers of a particular commodity tends to raise the price of that commodity, and if it did not so raise it the producer would be under a disadvantage as compared with all other producers; he would no longer gain the general and ordinary profits by his trade. ... If no protecting duty is imposed on the importation of a similar commodity from other countries, injustice is done to the producer at home, and not only to the producer but to the country to which he belongs. It is for the interest of the public that he should not be driven from a trade which, under a system of free competition, he would have chosen, and to which he would adhere if every other commodity were taxed equally with that which he produces. A tax affecting him exclusively is, in fact, a bounty to that amount on the importation of the same commodity from abroad; and to restore competition to its just level, it would be necessary not only to subject the imported commodity to an equal tax, but to allow a drawback of equal amount on the exportation of the home-made commodity. ${ }^{13}$

From Ricardo's writings, it is usually understood that BTAs should only be applied to taxes "which fall[] exclusively on the producers of a particular commodity' and not to income taxes or taxes that 'equally affect[] all classes of producers', which are assumed not to affect the relative value of goods. ${ }^{14}$

The distinction between specific and general taxes was later replaced by the distinction between indirect taxes (eligible for adjustments) and direct taxes (ineligible for adjustments). Moreover, the assumption that income taxes should not be compensated with adjustments has been called into question. In the 20th century authors indeed called into question the relevance of the distinction between consumption and production taxes (or indirect and direct taxes) as a valid eligibility criterion for BTAs (Chapter 5).

The fact that BTAs allow compensating for the impact of specific domestic consumption taxes on the relative value of goods should be put in perspective with Ricardo's most important legacy: the theory of comparative advantage. ${ }^{15}$ This theory - often described as the classic

13 Ibid., section iii: 'On the Effects of Taxes Imposed on a Particular Commodity'. See also David Ricardo, On the Principles of Political Economy and Taxation (John Murray 1817), chapter 16.42, available at <http:// www.econolib.org/library/Ricardo/ricP.htlm> (accessed 21 January 2014); David Ricardo, On Protection to Agriculture (London William Clowes John Murray, Albermarle-Street 1822), 15.

14 Ricardo, supra n. 12, section iii.

15 The theory of comparative advantage is not only attributed to David Ricardo but also to Robert Torrens and James Mill. See John Aldrich, 'The Discovery of Comparative Advantage' (2004) 26(3) Journal of the History of 
economic rationale for free trade - is a refinement of Adam Smith's theory on the absolute advantage, which explains international trade by reference to the differences in absolute costs of production between countries. ${ }^{16}$

In contrast to the theory of absolute advantage, the theory of comparative advantage is based on the idea that any country may benefit from international trade given that all countries have a relative advantage in the production of certain goods. ${ }^{17}$ The theory on comparative advantage is best illustrated by Ricardo's famous example of trade between Portugal and England. Though the production of cloth and wine is - in absolute terms - less efficient in England than in Portugal, England may have a comparative advantage in producing cloth when the ratio of the price of cloth between England and Portugal is lower than the ratio of the price of wine between England and Portugal. ${ }^{18}$ In this example, the relative advantage of producing wine in Portugal is based on differences in labour

Economic Thought 379; Leonard Gomes, The Economics and Ideology of Free Trade: A Historical Review (Edward Elgar Publishing 2003), 40; Andrea Maneshi, Comparative Advantage in International Trade. A Historical Perspective (Edward Elgar Publishing 1998); Roy J. Ruffin, 'David Ricardo's Discovery of Comparative Advantage' (2002) 34(4) History of Political Economy 727-748.

16 Daniel Bethlehem, Donald McRae \& Rodney Neufeld, The Oxford Handbook of International Trade Law (OUP 2009), 7-9; Raj Bhala, International Trade Law: Interdisciplinary Theory and Practice (Lexis Law Publishing 2008), 201-240; Daniel C.K. Chow \& Thomas J. Schoenbaum, International Trade Law: Problems, Cases and Materials (Wolters Kluwer Law \& Business 2013), 32-33; Simon Lester, Bryan Mercurio \& Arwel Davies, World Trade Law: Text, Materials and Commentary (Hart 2012), 21-24; Peter Van den Bossche \& Werner Zdouc, The Law and Policy of the World Trade Organization (CUP 2013), 17-19. See also Reinhard Schumacher, 'Adam Smith's Theory of Absolute Advantage and the Use of Doxography in the History of Economics' (2012) 5(2) Erasmus Journal for Philosophy and Economics 54-80. See also Adam Smith, An Inquiry into the Nature and Causes of the Wealth of Nations (Edwin Cannan, Methuen \& Amp, 1776 Library of Economics and liberty 1904), IV.2.12, available at <http://www.econolib.org/library/Smith/smWN13.htlm> (accessed 23 January 2014).

17 Ruffin, supra n. 15. See also OECD, Trade Principles and Concepts, 1995, OECD/DG(95)141, 5.

18 Gomes, supra n. 15, 36-37. See also the original work of Ricardo (Ricardo, On the Principles of Political Economy and Taxation, supra n. 13, chapter 7.7.16). 
cost: it requires relatively less 'men' (i.e. labour) to produce wine in Portugal than in England. ${ }^{19}$

The theory of comparative advantage entails a normative message: countries will benefit from trade when production takes place in accordance with the comparative advantage theory. ${ }^{20}$ As far as taxation is concerned, the normative message of the comparative advantage theory is the following: trade in accordance with the comparative advantage principle is only possible when tax neutrality prevails. Here, tax neutrality means that tax systems should not influence economic decisions. ${ }^{21}$ To ensure tax neutrality, two main principles should be followed. The first principle - very intuitive - requires that countries refrain from using tax measures with trade-restrictive effects (i.e. tariffs). ${ }^{22}$ In contrast, the

19 Note, however, that the neo-classical understanding of comparative advantage uses other factors to explain countries' comparative advantage in producing certain goods, such as differences in technology and factor endowments such as land, labour and capital. See Bernard Lassudrie-Duchêne \& Deniz Ünal-Kesenci, 'L'avantage comparatif, notion fondamentale et controversée', L'Economie Mondiale en 2002 (La découverte 2001), 90-104. On the EckserOhlin theory, see Theo S. Eicher, John H. Mutti \& Michelle H. Turnovsky, International Economics (Routledge 2009), 66-106.

20 A. Lans Bovenberg \& Jocelyn P. Horne, 'Taxes on Commodities. A Survey', in: George Kopits (ed.), Tax Harmonization in the European Community: Policy Issues and Analysis (1992) 34 IMF Occasional Papers, 22; Eicher, Mutti \& Turnovsky, supra n. 19, 13-33; Gomes, supra n. 15, 39. See also Ricardo, On the Principles of Political Economy and Taxation, supra n. 13, chapter 7, para. 6 .

21 On the concept of 'tax neutrality' in other contexts, see Catherine Brown \& Jack Mintz, 'On the Relationship between International Tax Neutrality and Non-Discrimination Clauses under Tax Treaties for Source-Based Taxes', in: Michael Lang, Pasquale Pistone et al. (eds.), Tax Treaties: Building Bridges between Law and Economics (IBFD 2010), 581; George Kopits, 'Overview', in: George Kopits, Tax Harmonization in the European Community: Policy Issues and Analysis (1992) 34 IMF Occasional Papers, 6; Cees Peters, 'International Tax Neutrality and Non-Discrimination: Plea for a More Explicit Dialogue between the State and the Market', in: Michael Lang, Pasquale Pistone et al. (eds.), Tax Treaties: Building Bridges between Law and Economics (IBFD 2010), 607. In the specific context of VAT, see Thomas Ecker, A VAT/GST Model Convention (IBFD Doctoral Series 2013), 103 et al.; Charlène Adline Herbain, VAT Neutrality (Promoculture Larcier 2015); Ben Terra \& Julie Kajus, A Guide to the European VAT Directives. Introduction to European VAT 2012 (IBFD 2013, Vol. 1), 289-293. See also OECD, OECD International VAT/GST Guidelines, Draft Consolidated Version. Invitation for Comments, February 2013.

22 Ricardo, On the Principles of Political Economy and Taxation, supra n. 13 , chapter 7 , para. 34 . 
second principle requires that countries adopt tax adjustments to ensure that specific consumption taxes do not affect international trade. In other words, BTAs are a condition to guarantee that international trade takes place in accordance with the theory of comparative advantage.

Under Ricardo's model, taxation only - in contrast to other policies or situations - seems to call for compensating measures to ensure 'fair competition' between countries. In chapter 7 of his book $O n$ the Principles of Political Economy and Taxation, Ricardo distinguishes between the trade effects of taxation and other elements such as climate and manufacturing skills. He writes as follows:

These [i.e. climate and skill/machinery] I believe to be the only two causes which regulate the comparative value of money in the different countries of the world; for although taxation occasions a disturbance of the equilibrium of money, it does so by depriving the country in which it is imposed of some of the advantages attending skill, industry and climate. ${ }^{23}$

Besides taxation, Ricardo does not discuss in much detail the effect of non-tax elements such as climate, skill and machinery. The question therefore arises as to the trade impact of non-fiscal policies: in addition to climate and manufacturing skills, non-fiscal policies, such as environmental standards, could also affect the relative cost of products. ${ }^{24}$ Ricardo's model does not elaborate on the impact of these policies and on the potential need to compensate for their trade effects. One possible explanation is that Ricardo assumes that regulatory measures are - by definition - general measures, which means that they affect all producers equally without having an impact on the relative price of goods. This hypothesis is likely to be true for most domestic policies (education, labour standards, infrastructure, etc.). ${ }^{25}$ Environmental standards, however, may arguably affect the relative value of goods as soon as they are applied to a limited number of goods.

23 Ibid., para. 44.

24 See Alexander Gillespie, 'The Contradiction between Comparative Advantage in International Trade and Environmental Protection' (1995) 3 Waikato Law Review 129. See also OECD, Working Party No. 4 of the Council on border tax adjustments, Remarks on the United States Member of the Working Party at the 2nd Session on 2nd July 1965, Paris, 8th July 1965, C/WP4(65)3, 5.

25 This distinction is particularly interesting as it has often been argued that adjustments for environmental purposes could lead to unlimited adjustments for any other purpose (e.g. in the field of social policies). 
In the literature the concept of 'comparative advantage' is often confused with the concept of 'competitive advantage'. ${ }^{26}$ The two concepts, however, rely on fundamentally different assumptions and should therefore be distinguished. The notion of competitive advantage cannot be captured in one single definition. ${ }^{27}$ In legal scholarship, the term is usually defined by reference to absolute differences in the price of goods. ${ }^{28}$ In other words, the concept is based on the assumption that trade flows are explained by the absolute advantage that a country has for producing certain goods. ${ }^{29}$ The distinction between the two concepts also appears in the normative message that they entail. Under the concept of comparative advantage, BTAs are only necessary in respect of specific taxes. In contrast, it could be derived from the theory on competitive advantage that BTAs should be adopted in respect of any tax (and any policy) that is assumed to be shifted into products' prices. Indeed, the theory of competitive advantage assumes that trade flows are distorted as soon as a tax is passed into a product's price, which would explain the need for BTAs (Section 1.3).

26 Donald H. Regan, 'How to Think about PPMs (and Climate Change)', in: Thomas Cottier et al. (eds.), International Trade Regulation and the Mitigation of Climate Change. World Trade Forum (CUP 2009), 5. What Regan calls 'normative comparative advantage' seems to be closer to the notion of absolute advantage. See also Gillespie, supra n. 24, 130; Gilbert E. Metcalf \& David Weisbach, 'The Design of a Carbon Tax' (2009) 33 Harvard Environmental Law Review 499, 540; Eckhard Siggel, 'The Many Dimensions of Competitiveness' (2007), CESifo Venice Summer Institute; Chris Wold, Sanford Gaines \& Greg Block, Trade and the Environment. Law and Policy (Carolina Academic Press 2005), 31-32.

27 See Satya Dev Gupta, 'Comparative Advantage and Competitive Advantage: An Economics Perspective and a Synthesis' (2009), available at <http:// economics.ca/2009/papers/0534.pdf> (accessed 28 October 2015).

28 Robert Howse, The WTO System: Law, Politics \& Legitimacy (CUP 2007), 115. See also, in the economic literature: John C. Dunmore, 'Competitiveness and Comparative Advantage of US Agriculture', Paper presented at the 1986 National Public Policy Education Conference, Denver, Colorado, 16 September 1986; Harry Johnson \& Mel Krauss, 'Border Taxes, Border Tax Adjustments, Comparative Advantage, and the Balance of Payments' (1970) 3(4) Canadian Journal of Economics 595-602.

29 Howse, supra n. 28, 115. See also Wold, Gaines \& Block, supra n. 26, $31-32$. 


\subsection{BTAs’ POLITICAL HISTORY}

The economic analysis of BTAs has largely influenced their long political history. References to the economic debate introduced by Ricardo have often accompanied BTAs' political developments. Nevertheless, later political views on BTAs have not always mirrored Ricardo's theoretical contribution (Section 1.2.1). Moreover, the OECD 1968 and GATT 1970 reports illustrate that important political claims have been expressed against BTAs' economic rationale (Section 1.2.2). Subsequent international, regional and national developments similarly highlight the controversial issues surrounding current BTA practices (Section 1.2.3). Proponents of the introduction of environmental BTAs should be aware of this controversial legal context to be prepared for answering criticisms of their proposals. Indeed, the integration of environmental considerations is likely to make BTAs even more controversial.

\subsubsection{First BTAs}

The first BTAs date back to the 18th century. ${ }^{30}$ As early as 1791, the US had an excise tax that was border adjusted, at least upon exports. ${ }^{31}$ In the 'Whiskey Act', the adjustment on exports aimed at 'the encouragement of the export trade of the United States' ${ }^{32}$

Interestingly, the legislative rationale given at the time to explain the adoption of border adjustments on exports (i.e. the 'encouragement of exportation') seems to be contrary to its supposed economic rationale (i.e. achieving free trade in accordance with the theory of comparative advantage). Other later examples show that BTAs were not always justified based on the 'trade neutrality' argument. For example, the Danish Minister of Finance advocated the introduction of a value-added tax in the 1960s, considering that 'for the sake of Danish ability to compete, it would be no doubt to be to our advantage if we could act as pioneers in this field ...' ${ }^{33}$

30 Hufbauer, supra n. 11, 21-22. See also OECD 1994 note on Environmental BTAs, COM/ENV/EPOC/DAFFE/CFA(94)31, 4, para. 7.

31 Ibid.

32 Stewart, Salonen \& McDonough, supra n. 11, 23 quoting Sec. 51 of US, Act of 3 March 1791.

33 Paul Gersman, 'Value-Added Tax' (1965) 19 The OECD Observer 39. This document is referred to by Leontiades in: Milton Leontiades, 'The Logic of Border Taxes' (1966) 19(2) National Tax Journal 173, 183. 


\subsubsection{International Fora on BTAs: The OECD and GATT Reports on BTAs}

In the 20th century, two important fora discussed the issue of BTAs in an international context: the OECD in 1968 and the GATT in 1970. These discussions can be understood in the context of US criticisms against European tax systems increasingly relying on indirect taxes and related BTAs. ${ }^{34}$

\subsubsection{Role of the OECD and the GATT in tax matters}

The OECD was established on 14 December 1960 in Paris, replacing the Organisation for European Economic Co-operation (OEEC) created in 1948. ${ }^{35}$ Neither the Convention of 1948 nor the Convention on the OECD contains provisions directly referring to taxation. It is, however, not surprising that taxation plays a significant role in the OECD in the light of the main objectives of the organisation: 'to achieve the highest sustainable economic growth', 'to contribute to sound economic expansion' and 'to contribute to the expansion of world trade on a multilateral, non-discriminatory basis in accordance with international obligations'. ${ }^{36}$ Moreover, as early as 1956, a Fiscal Committee was established within the OEEC. ${ }^{37}$ Nowadays, in tax matters, the OECD - in particular, the Committee on Fiscal Affairs and the Centre for Tax Policy and Administration - is well known for its work on transfer pricing and the OECD Model Tax Convention on Income and Capital. ${ }^{38}$ In recent years the

34 Rosendahl gives a very good summary of the political debate surrounding BTAs in the 1970s (Roger W. Rosendahl, 'Border Tax Adjustments: Problems and Proposals' (1970) 2 Law \& Policy in International Business 85). See also Johnson \& Krauss, supra, n. 28, 595 ('US public opinion has been very critical of the decision of certain Common Market and other European countries to move to a system of value added taxes on the destination principle, which change has been seen as harmful to the United States balance of payments position').

35 Convention on the Organisation for Economic Co-operation and Development, Paris, 14 December 1960 (hereafter, 'OECD Convention').

36 Article 1 of the OECD Convention.

37 See Farrell, supra n. 9, 25. This Committee is now named the Committee on Fiscal Affairs.

38 The Centre for Tax Policy and Administration can be described as one of the 'departments' of the OECD. Other 'departments' listed on the OECD website are i.a. the 'Development Co-operation Directorate', the 'Economics Departments', the 'Directorate for Education and Skills', the 'Directorate for Employment, Labour and Social Affairs', the 'Environment Directorate', the 'Trade and 
OECD has been working on aggressive tax planning, including the BEPS ('Base Erosion and Profit Shifting') action plan.

The tariff negotiations that preceded the adoption of the GATT may explain its role, as an organisation, in tax matters. ${ }^{39}$ The text of the GATT contains direct references to taxation, mainly customs duties and other indirect taxes, including provisions that define the legal framework surrounding the adoption of BTAs. ${ }^{40}$ In contrast to the Convention for European Economic Co-operation, which was intended to "create the conditions and establish the institutions necessary for the success of European economic cooperation ...', the GATT introduced substantive legally binding obligations upon its members. ${ }^{41}$ The different purposes of the two organisations may explain the lack of cooperation between the actions undertaken at the OECD and GATT levels. One of the few exceptions concerns the topic of BTAs, where information was exchanged between the OECD and the GATT Council in the late 1960s. ${ }^{42}$ On 1 January 1995, the GATT was replaced by the WTO. ${ }^{43}$ The organisation is now made up of 164 countries. $^{44}$

\subsubsection{Background of the reports}

In the 1960s the US started to express concerns about the potential effects of BTAs on international trade, considering that the proposals to

Agriculture Directorate', etc. See the website of the OECD at <www.oecd.org > (accessed 11 November 2015).

39 Farrell, supra n. 9, 24.

40 See i.a. GATT Arts. I, II, III, VI, VII, VIII, X, XI. Farrell, supra n. 9, 24. Farrell considers that 'notwithstanding the narrow focus of the GATT 1947 and the failure of the ITO, the GATT 1947 contracting parties did not automatically assume that matters relating to direct taxation would fall outside the scope of the Agreement' (p. 24).

41 See Convention for European Economic Co-operation, preamble.

42 See Farrell, supra n. 9, 27, footnote 91. See also GATT, Minutes of Meeting held at the Palais des Nations on 27-28 March 1968, 5 April 1968, C/M/46, 11 (hereafter, 'GATT, C/M/46'); OECD, Council, Relations with the G.A.T.T. Report by the Trade Committee, Paris, 31 October 1961, OECD/ C(61)45; OECD, Council, O.E.C.D. Documentation on Border Tax Adjustments. Request from the Director-General of the GATT (Note by the SecretaryGeneral), Paris, 3 May 1968, C(68)60.

43 WTO, Marrakesh Agreement Establishing the World Trade Organization, 15 April 1994; WTO, 'The 128 countries that had signed GATT by 1994', available at <http://www.wto.org> (accessed 27 January 2014).

44 WTO, 'Members and Observers', available at <https://www.wto.org/ english/thewto_e/whatis_e/tif_e/org6_e.htm> (accessed 4 July 2017). 
modify the turnover tax systems in Europe - in particular, the German turnover tax - could have a negative impact on free trade. ${ }^{45}$ According to the US:

Tax systems had changed considerably since the GATT provisions on border tax adjustments had been drafted and a more sophisticated view of the effects of these would be taken today. Border tax adjustments had been expanded and developed in response to changes in tax systems at a time when tariffs and other barriers to trade were being progressively reduced. Border tax adjustments had, therefore, come to have relatively greater importance. ${ }^{46}$

In other words, BTAs - which were not considered an important issue at the time of the adoption of GATT provisions - became a policy issue for the US at the end of the 1960s. ${ }^{47}$ Consequently, the US requested the OECD Council and the GATT to study the situation of tax adjustments. ${ }^{48}$ Following this request, the OECD Secretariat released in 1964 a 'factfinding report on border tax adjustments applied by member countries to exports and imports'. This report is organised in two parts: the first part analyses the various forms of BTAs as well as their effects; the second part presents the situation in member countries. ${ }^{49}$ Later, a Working Party

45 See OECD, Council, Statement by the United States representative in the O.E.C.D. Council on the prospective increase of the German Equalisation tax, Paris, 22 May 1962, C(62)91.

46 GATT, C/M/46, supra n. 42, 8. See also Stewart, Salonen \& McDonough, supra n. $11,33-37$.

47 GATT, Working Party on Border Tax Adjustments, Meeting of 30 April to 2 May 1968, Note by the Secretariat, 17 May 1968, L/3009, Annex, 9 (US Statement) (hereafter, 'GATT, L/3009').

48 See, at the OECD level, OECD, Council, Minutes of the 49th Meeting held at the Château de la Muette, Paris, on Tuesday, 30 July 1963, C/M(63)15 (Prov.), 16 August 1963, item 154, 9; OECD, Working Party No. 4 of the Council on Border Tax Adjustments, The United States Submission on Border Tax Adjustments, Paris, 16 February 1966, C/WP4(66)4; OECD, C(62)91. At the GATT level, see GATT, Border Tax Adjustments. Proposed Terms of References for Working Party, 27 March 1968, C/W/123 (hereafter, 'GATT, C/W/123').

49 OECD, Council, Fact-finding report on border tax adjustments applied by member countries to exports and imports (note by the Secretariat of the Council), Paris, 12 October 1964, C(64)137 Part I and Part II. See also OECD, Trade Committee, Border Tax Adjustments, Consultation Procedure, Arrangements adopted by the Trade Committee, Paris, 23 June 1967, TC(67)14; OECD, Related Activities Division, Fact-finding report on border tax adjustments applied by member countries to exports and imports, Paris, 13 November 1967. 
on BTAs was established both at the OECD level (in 1965) and at the GATT level (in 1968). ${ }^{50}$

At the OECD level, the objective was to give an overview of BTAs and tax structures of OECD member countries as in March 1967.51 In that sense, the report has mainly an informative value: the report does not reflect the views of the member countries with the exception of the 'country chapters' on which countries have given their agreement. ${ }^{52}$

At the GATT level, the mandate of the Working Party was to examine BTAs in light of the relevant GATT provisions, the practices of contracting parties and their possible effects on international trade. ${ }^{53}$ The US hoped-for result was to achieve a common agreed interpretation - if not a modification - of the GATT provisions surrounding BTAs in order to prevent future disagreements between parties. ${ }^{54}$ Areas of anticipated difficulties were the following: the use of averaging in respect of certain taxes, the effect of BTAs on international trade and the effect of changes in domestic taxes on international trade, in particular the impact on countries' balance-of-payments positions. ${ }^{55}$ Members of the GATT reacted positively to the US request though not all parties agreed with the way the US had presented the issues at stake. ${ }^{56}$

To avoid replicating the work of the OECD on BTAs, the GATT secretariat was authorised to request OECD working papers and documents produced on the topic. ${ }^{57}$ Moreover, in order to collect information

50 For the OECD, see OECD Report on tax adjustments applied to exports and imports in OECD member countries, 1968, 16, para. 6 (hereafter, 'OECD 1968 Report'); OECD, Ad Hoc Group of the Trade Committee, Consultation on Changes in Border Tax Adjustments in Germany, Date of the next meeting, Paris, 28 November 1967. For the GATT, see GATT, C/W/123, supra n. 48.

51 Consequently, only the situation of the original 20 members and Japan is analysed in the report. Where some members have modified their tax structures between March 1967 and March 1968, changes are in principle indicated in footnotes (see OECD 1968 Report, supra n. 50, 11 (foreword)).

52 OECD 1968 Report, supra n. 50, 11 (foreword).

53 GATT, C/W/123, supra n. 48; GATT, Border Tax Adjustments. Proposed Terms of Reference for Working Party, 28 March 1968, C/W/124. See also GATT, C/M/46, supra n. 42.

54 GATT, C/M/46, supra n. 42, 8-9. See also GATT, L/3009, supra n. 47, Annex, 10; GATT, Working Party on Border Tax Adjustments, Meeting of 8 to 11 October 1968, Note by the Secretariat, 23 November 1968, L/3125, Annex, 21.

55 GATT, C/M/46, supra n. 42, 8-9. See also the paragraphs concerning the US balance-of-payments difficulties.

56 GATT, C/M/46, supra n. 42, 10-11.

57 Ibid., 11. 
on BTA practices in non-OECD member countries, a questionnaire based on a simplified version of the OECD questionnaire was prepared and sent by the secretariat to these countries. ${ }^{58}$

\subsubsection{Highlights}

1.2.2.3.1 Definition of BTAs One of the most important contributions of the OECD report is its definition of BTAs. The GATT 1970 report on BTAs confirmed this definition, referring to the OECD 1968 Report.59 Subsequent WTO reports also define BTAs by reference to the OECD 1968 Report. The OECD 1968 Report defines BTAs - also called 'equalisation taxes' in the report ${ }^{60}-$ as follows:

While border tax adjustments may be defined in various ways, it is most convenient for dealing with the problems which they present to regard them as any fiscal measures which put into effect, in whole or in part, the destination principle (i.e. which enable exported products to be relieved of some or all of the tax charged in the exporting country in respect of similar domestic products sold to consumers on the home market and which enable imported products sold to consumers to be charged with some or all of the tax charged in the importing country in respect of similar domestic products) (emphasis added). ${ }^{61}$

This definition calls for three main comments.

First, BTAs are defined as a fiscal mechanism based on the destination principle, which seems to be understood as a principle that allows imposing domestic taxes on imports while relieving exports from those taxes. This (trade-based) understanding of the destination principle does not fully match the one it has been given in other instances. Indeed, in other contexts (e.g. in the tax context), the destination principle has been defined by reference to the fact that taxes on products should be collected

58 GATT, L/3009, supra n. 47, 7, para. 26. See also GATT, Border Tax Adjustments, Questionnaire, 6 June 1968, Spec(68)56. Note OECD members were also requested to update the OECD information (L/3009, 7, para. 26).

59 GATT, Working Party on Border Tax Adjustments, Report, 2 December 1970, L/3464 (hereafter, 'GATT 1970 Report'). See also GATT, Working Party on Border Tax Adjustments, Meeting of 16 and 17 July 1968, Note by the Secretariat, 27 July 1968, L/3048, para. 6. Note that the Fact-Finding Report was distributed in attachment of $\operatorname{Spec}(68) 57$ (Spec(68)57/Add.1 and Spec(68)57/ Add.2).

60 OECD 1968 Report, supra n. 50, para. 68.

61 Ibid., 16, para. 6. 
in the country of destination, namely where goods are consumed. ${ }^{62}$ The destination principle is then opposed to the origin principle, according to which goods are taxed where they are produced. ${ }^{63}$

Second, the OECD definition of BTAs is voluntarily not limited to the 'taxes rebated on the occasion of exportation' and the taxes 'levied on the occasion of importation'. ${ }^{64}$ Indeed, such a restrictive definition would exclude taxes with similar effects (such as retail sales taxes or singlestage wholesale taxes) as soon as these taxes are not charged on imports and rebated on exports 'at the time of the crossing of the border' ${ }^{65}$ According to the report, this practical difference is not relevant: it is only a 'technical question relating to what is administratively the most convenient under the particular system of consumption tax in operation'. ${ }^{66}$ Moreover, as long as the economic effects of these taxes remain the same, the report indicates that it does not matter whether they are applied at the time when the border is crossed or not. ${ }^{67}$ For this reason, the GATT report points out that the concept of BTAs is confusing because it implicitly suggests that the tax should be adjusted 'at the border'. ${ }^{68}$ The GATT Working Party therefore recommends speaking about 'tax adjustments applied to goods entering into international trade' instead of BTAs. ${ }^{69}$

Third, the OECD and GATT reports distinguish between BTAs, customs duties and other barriers to trade. The distinction between these measures is, however, not always clear cut. For example, taxes on 'imports of a kind which would be taxable if home-produced, but which are in practice not home-produced' should preferably be considered as customs duties rather than as BTAs due to their potential protective effects. ${ }^{70}$ The report, however, assimilates the duties on goods such as 'imported tobacco, alcoholic drinks and hydrocarbon oils' to BTAs for 'methodological' purposes. ${ }^{71}$ Two reasons are put forward: first, these duties usually do not aim at protecting domestic industry and second, the

62 OECD, Taxing Consumption, 1988, para. 7.4. See also Hufbauer, supra n. $11,23$.

63 See Hufbauer, supra n. 11, 23. The two different understandings of the destination principles are analysed in more details in Chapters $3 \& 5$.

64 OECD 1968 Report, supra n. 50, 68, para. 115.

65 Ibid.

66 Ibid.

67 Ibid.

68 GATT 1970 Report, supra n. 59, para. 5.

69 Ibid.

70 OECD 1968 Report, supra n. 50, para. 38.

71 Ibid., para. 78 and para. 197. 
effects of customs duties and excise duties are difficult to distinguish when so-called 'excise duties' are applied to goods which are not domestically produced (or at least not produced in significant quantities). ${ }^{72}$ From a legal viewpoint, however, the qualification of these taxes as BTAs instead of customs duties may have a significant impact. Whereas the rate of customs duties may be strictly limited through WTO members' schedules of concessions (i.e. WTO members' commitments regarding tariffs), BTAs' tax rate may be as high as the rate of taxes imposed on like domestic products. Consequently, in the hypothesis where goods are not produced domestically, the designation of taxes on imports as BTAs would allow countries to freely increase tax rates on imports. ${ }^{73}$ In other words, in this case, the methodological choice to assimilate such taxes to BTAs would a priori offer member countries a significant margin of appreciation as to the rates imposed on imported goods.

1.2.2.3.2 Taxes eligible for BTAs In the OECD report, taxes that are considered eligible for adjustments under international practice are referred to as 'consumption taxes'. ${ }^{74}$ The report distinguishes between two main categories of consumption taxes: general consumption taxes (including 'single-stage taxes', 'multi-stage non-cumulative taxes' and 'multi-stage cumulative taxes') and specific consumption taxes ('traditional excises'). ${ }^{75}$ Though the OECD report uses the same distinction between general and specific taxes as the one made by Ricardo, the

72 Ibid.

73 This reasoning, however, does not hold for products that are not subject to substantial tariff commitments. See e.g. Melaku Geboye Desta, 'The GATT/ WTO System and International Trade in Petroleum: an Overview' (2003) 21 Journal Energy \& Natural Resources Law 393: ‘ ... the tariff schedules of GATT contracting parties typically contained hardly any binding tariff commitments in the petroleum sector. Thus, although applied tariffs on petroleum imports are generally low, WTO member countries are free to raise them to any desired levels - provided they remained unbound ...'. See also Susan L. Sakmar, 'Bringing Energy Trade into the WTO: The Historical Context, Current Status, and Potential Implications for the Middle East Region' (2008) 18 Indiana International \& Comparative Law Review 89, 96-97.

74 OECD 1968 Report, supra n. 50, para. 7. Note also that the report mentions - in a footnote p. 16 - few concrete examples of BTAs in respect of other taxes (i.a. the Greek social security charges and payroll taxes, the Spanish property taxes, stamp duties and parafiscal charges and, to some extent, the Turkish payroll and property taxes and the Italian registration and stamp duties).

75 Ibid., para. 9. 
report does not use this distinction as a criterion to determine which taxes are eligible for adjustments. The OECD report indeed highlights that countries' practices allow for BTAs in respect of consumption taxes, regardless of their general or specific character. ${ }^{76}$

The report recognises that the concept of 'consumption taxes' may be criticised given that not all goods can be classified as 'consumer goods'. ${ }^{77}$ Yet, the report favours the concept of 'consumption tax' over the terms 'indirect tax' (considered too broad) and 'turnover tax' (considered too restrictive). Moreover, the OECD report explains that the distinction between direct and indirect taxes is not appropriate due to the difficulty in classifying taxes as direct or indirect taxes and the 'oversimplification' of assimilating indirect taxes to eligible taxes for adjustments and direct taxes to non-eligible taxes for adjustments. ${ }^{78}$ This last argument is rather weak given that the concept of consumption taxes could also be considered an artificial categorisation of the taxes subject to BTAs.

The artificial character of the distinctions used to determine the taxes that should be eligible for BTAs also appears in the GATT report. Indeed, in contrast to the OECD report, the GATT Working Party report distinguishes between direct and indirect taxes (instead of distinguishing between consumption and non-consumption taxes) as a criterion for determining the eligibility of taxes for BTAs, which illustrates the lack of coherence and rational arguments for preferring one distinction over another. Some members of the Working Party rightly criticised the distinction between direct and indirect taxes during the preparatory

76 See OECD, Working Party No. 4 of the Council on Border tax adjustments, remarks by the German Member of the Working Party, at the 3rd Session on 20 September 1965, Paris, 1 October 1965, C/WP4(65)7, 3-4:

it has been argued that some adjustment at the frontier for an isolated excise tax, not however for a general excise tax, can be justified by economic theory, since a general tax affects the overall price level while the isolated tax alters the relative price relationships among domestic products. This argument is based on the assumption that the general excise is imposed at no more than one standard rate, but that is mostly not the case. As example, I should like to refer to the variety of rates at which the German turnover tax, the U.K. purchase tax and the French TVA are being levied. Apart from that, it is a matter of legislative technique whether a tax is designed as a 'general' or an 'isolated' excise tax. As a theoretical proposition, one could imagine a multi-rate general excise tax being replaced by a multitude of isolated excise taxes.

77 OECD 1968 Report, supra n. 50, para. 8.

78 Ibid., para. 116. 
meetings. For example, the US pointed out the absence of a clear definition of the concepts of direct and indirect taxes:

The GATT itself does not refer to the distinction, and the report of the Experts Group on this question is ambiguous in many respects. This is not surprising. Even today, economists have difficulty in defining direct and indirect taxes, depending upon the conceptual framework within which they are working and the purpose for which they wish to find definitions. ${ }^{79}$

The concept of taxe occulte offers another - more concrete - example of the ineffectiveness of the distinctions mentioned in the reports (both the distinction between direct and indirect taxes and the distinction between consumption and non-consumption taxes). None of the reports reach a clear conclusion as to the eligibility of these taxes, which the OECD report describes as follows:

In addition to consumption taxes on goods themselves, there may be an element of tax paid in respect of goods or services used in their production or transportation. ... The hidden element of tax in an article, corresponding to the additional tax paid on any of these goods or services, is referred to ... as 'taxe occulte', and the goods or services themselves are referred to as 'producers' goods or services', though they may be used in certain cases by consumers. ${ }^{80}$

Examples of taxes occultes include taxes on 'auxiliary materials expended in the transportation or production of goods (e.g. energy, fuel, lubricants, packing, stationery)', taxes on 'durable capital equipment goods', taxes on 'services (e.g. transport, advertising)'. ${ }^{81}$ The OECD report notes that countries differ in the amount of taxes occultes arising out of consumption taxes. ${ }^{82}$ Moreover, the report points out the absence of a uniform practice as to BTAs in respect of taxes occultes arising out of consumption taxes. ${ }^{83}$ At the time of the OECD and GATT reports, the issue of taxes occultes was not considered to be of primary importance as, in practice, "adjustment was not normally made for "taxes occultes" except in countries having a cascade tax' ${ }^{84}$

79 GATT, L/3009, supra n. 47, Annex, 11. See also Leontiades, supra n. 33, 173-183.

80 OECD 1968 Report, supra n. 50, para. 19.

81 Ibid. See also GATT 1970 Report, supra n. 59, para. 15.

82 OECD 1968 Report, supra n. 50, paras. 20 \& 103.

83 Ibid., para. 105.

84 GATT 1970 Report, supra n. 59, para. 15. See also Memorandum from Secretary of the Treasury Kennedy, Washington, 30 June 1970, Washington 
The classification of eligible or non-eligible taxes for adjustments based on the OECD 1968 Report is summarised in Table 1.1. ${ }^{85}$

Table 1.1 Eligibility of taxes for adjustments in OECD 1968 and GATT 1970 reports

\begin{tabular}{ll}
\hline \multicolumn{1}{c}{ ELIGIBLE TAXES } & \multicolumn{1}{c}{ NON-ELIGIBLE TAXES } \\
\hline $\begin{array}{l}\text { Consumption taxes (OECD)/indirect } \\
\text { taxes (GATT) }\end{array}$ & $\begin{array}{l}\text { Other taxes (OECD)/direct taxes } \\
\text { (GATT) }\end{array}$ \\
\hline - General & o Income taxes \\
o Single-stage taxes (sales taxes) & o Profits taxes and corporate income \\
o Multi-stage non-cumulative taxes & taxes \\
(TVA) & o Capital gain taxes and wealth \\
o Multi-stage cumulative taxes & o taxes \\
(cascade taxes) & \\
- Specific & \\
o Traditional excises & \\
o Duties on tobacco, beer, wines, & \\
hydrocarbon oils, etc. & \\
o (State monopolies) & \\
\hline Exceptions, i.a.: & General: \\
o Social security charges in Greece & o Social security charges \\
o Property taxes & o Property taxes \\
o Stamp duties in Spain, etc. & o Payroll taxes \\
\hline
\end{tabular}

Taxe occulte

Eligibility varies depending on the tax from which the taxe occulte arises

1.2.2.3.3 BTAs' rationales The two reports give an overview of the arguments that have been put forward in favour or against the adoption of BTAs. A first argument in favour of BTAs concerns the objective of neutrality in international trade, as expressed by Ricardo. The reports, however, formulate BTAs' rationale not in terms of trade and tax neutrality but in terms of BTAs' neutrality: BTAs should be trade neutral

National Records Center, Department of the Treasury, Secretary's Memos/ Correspondence, FRC 5674 7, Council of Economic Advisers, Foreign Relations, 1969-1976, Vol. III, Foreign Economic Policy, 1969-1972, International Monetary Policy, 1969-1972, Document 42, available at <http://2001-2009. state.gov/r/pa/ho/frus/nixon/iii/5341.htm> (accessed 17 November 2015).

85 See OECD 1968 Report, supra n. 50, paras. 8-9, 74 \& 116-119. 
and have no influence on domestic taxation. ${ }^{86}$ This new formulation may be explained by the US claim that BTAs were not 'neutral'. The question of the neutrality of BTAs is directly linked to the shifting into prices of taxes eligible for BTAs. Where taxes eligible for BTAs are "not fully shifted into prices', BTAs could be suspected of benefiting countries relying heavily on consumption/indirect taxes. ${ }^{87}$ Both reports mention arguments in favour and against the hypothesis of price shifting (infra). ${ }^{88}$ A second argument in favour of BTAs is based on practical considerations: 'they would also be justified if it seems likely that any alternative practices would produce a less neutral situation as between different tax systems and/or would be more difficult to apply in practice' ${ }^{89}$ In other words, the reports recognised that the purpose of BTAs was not to achieve 'perfect fiscal neutrality in international trade' - given that this goal is very unlikely to be achieved in practice - but BTAs are considered a step in this direction. ${ }^{90}$

Aside from these two arguments in favour of BTAs, two additional arguments based on historical considerations are mentioned in the OECD and GATT reports to reject BTAs' economic rationale. A first negative view argues that GATT provisions cannot be explained based on strong economic grounds but should rather be considered a mere "codification of existing practices'. ${ }^{91}$ Given the move towards a stronger reliance on indirect taxes in certain countries in the 1960s-1970s, GATT provisions

86 Ibid., para. 112. See however OECD, Border tax adjustments applied by member countries to exports and imports, note by the secretariat of the Council, Paris, 27 January 1965, CES/65.08, 3 ('Summary of conclusions of a symposium on border tax adjustments organised by the secretariat on 17-19 September 1964').

87 GATT, L/3009, supra n. 47, Annex, 13.

88 For the OECD report, see OECD 1968 Report, supra n. 50, paras. 120-127. For the GATT, see GATT 1970 Report, supra n. 59, para. 21; GATT, Working Party on Border Tax Adjustments, Meetings of 23 to 25 April and 30 June to 3 July 1969 , Note by the Secretariat, L/3272, paras. 31-57 (hereafter, 'GATT, L/3272').

89 OECD 1968 Report, supra n. 50, paras. $113 \& 150$.

90 GATT, L/3272, supra n. 88, para. 83. GATT 1970 Report, supra n. 59, paras. 9 \& 13: 'The point was made that Revenue Departments ... had strong reason in the interest of the revenue as well as fiscal justice, to ensure, in the treatment of imports and exports, neutrality with home-produced goods' (para. 9).

91 GATT, L/3009, supra n. 47, para. 2. See also Stewart, Salonen \& McDonough, supra n. 11, 35 quoting John R. Petty, Assistant Secretary of Treasury for International Affairs, Paper prepared for the Twenty-first Annual Conference of the Canadian Tax Foundation (20 November 1968). 
no longer reflected the practices of the time and needed to be changed. ${ }^{92}$ A second negative argument - not directly touched upon by the reports but mentioned in the literature at that time - considers that BTAs' rationale is related to the introduction of a system of fixed exchange rates that prevailed after the Second World War. ${ }^{93}$ According to Baldwin, the purpose of BTAs should be read against this background: it could be argued that BTAs served as an instrument of monetary policy (as countries, in a fixed exchange rate system, could not freely modify their exchange rate) rather than as a tool for compensating for price shifting. ${ }^{94}$ On this view, the limitation of the eligibility of BTAs to indirect taxes (excluding direct taxes) could be seen as an arbitrary decision aimed at circumscribing the instruments of monetary policy available for countries. In other words, the distinction between direct and indirect taxes would not be grounded in any logical explanation other than the historical tradition of BTAs being adopted in respect of indirect taxes.

\subsection{BTAs' rationale based on the assumption of tax shifting As} mentioned above, tax shifting is the principal assumption underlying BTAs' main rationale (i.e. the argument that BTAs are trade neutral). Indirect/consumption taxes are eligible for BTAs because they are shifted into products' prices while direct/other types of taxes are not eligible because they are not shifted into prices. This assumption resembles Ricardo's theory in that a key element of BTAs' rationale is tax shifting.

92 GATT, L/3009, supra n. 47, Annex, 9-10.

93 The US indirectly mentioned this argument by referring to US balanceof-payments difficulties (GATT, C/M/46, supra n. 42, paras. 1-9). See also GATT 1970 Report, supra n. 59, para. 26; GATT, L/3272, supra n. 88, paras. 31-37 and GATT, L/3009, supra n. 47, Annex, 12-13.

94 See Robert E. Baldwin, Nontariff Distortions of International Trade (George Allen \& Unwin Ltd 1970). See e.g. p. 89:

Even though they were aware that other countries relied more heavily on indirect taxes and therefore would be able to claim higher border adjustments, they conceived of the rule as a helpful device in overcoming the widespread scarcity of dollars.

See also p. 96 :

Since general and uniform border adjustment changes by themselves are equivalent to a change in the foreign price of a country's currency, an important criterion for judging them is whether the effective alteration in the exchange rate tends to bring about equilibrium in the balance of payments.

See also Roy Blough, 'The Adjustment Process and the International Role of the Dollar' (1969) 24(2) The Journal of Finance 345-359. 
It nevertheless differs from Ricardo's theory in that it does not consider whether the tax has a general or specific influence on the relative value of goods. In other words, both reports suggest that, as soon as price shifting can be proven, the tax should be eligible for BTAs. From this perspective, BTAs' economic rationale in the OECD and GATT reports does not match Ricardo's economic claim but better reflects the theory of absolute advantage, BTAs' role being to neutralise the effects of taxes on absolute prices.

This assumption of tax shifting is discussed in both reports, from two different perspectives. First, the reports analyse whether indirect/ consumption taxes are effectively fully shifted into products' prices, without reaching any clear-cut conclusion. ${ }^{95}$ Second, both reports put into question the measures in respect of which BTAs may be adopted. Indeed, when BTAs' rationale is grounded in the fact that BTAs compensate for tax shifting, the question arises as to whether BTAs may be applied (1) in respect of any tax (including direct taxes), and (2) in respect of non-tax policies as soon as it can be proven that these tax and non-tax policies have been shifted into products' prices. ${ }^{96}$

As to the eligibility of direct/non-consumption taxes for BTAs, the OECD report refers to economic studies carried out in the UK and the US concerning the shifting of profit taxes: 'In general, it seems that studies in the United States usually indicate a greater degree of shifting than studies in the United Kingdom, though it is not clear whether this reflects a difference in actual shifting or in the type of enquiry conducted

95 OECD 1968 Report, supra n. 50, paras. 129-149 (para 140: 'In the absence of agreement on the degree of shifting of consumption taxes there remains no agreement on the economic rationale of allowing border adjustments in full for consumption taxes'). See also GATT 1970 Report, supra n. 59, para. 22.

96 See OECD 1968 Report, supra n. 50, para. 153:

if they [corporation income taxes] are so shifted, it is argued that in the absence of border tax adjustments, commodity flows are distorted by profits tax differentials and that a country with a high rate of profits tax is consequently at a trade disadvantage.

See also, GATT, L/3009, supra n. 47, Annex, 11:

When governments adopt new domestic economic policies which have side effects on trade or payments, domestic action is not necessarily accompanied by offsetting action to neutralize the balance-of-payments effect. Many government actions, for example, affect general price levels. But only in the case of indirect tax measures is there an institutionalized provision for such offsets. What is the characteristic of indirect taxation that makes it uniquely qualified for automatic border adjustments? 
in these different countries. ${ }^{97}$ It is noteworthy that the differing results between the US and the UK match the political agenda of these countries at the time.${ }^{98}$ Hence, the question arises as to whether the political debate has been grounded in differing empirical results put forward by researchers in both countries or whether economic research (and the methods favoured) have been influenced by political considerations.

Overall, the reports point out practical difficulties related to the implementation of BTAs in respect of direct/non-consumption taxes. ${ }^{99}$ The reports note that it may be difficult to determine the trade effects of such taxes, which means that adjustments will necessarily be based on averaging. ${ }^{100}$ This observation could be criticised as it rests on the assumption that consumption taxes are fully shifted forward into products' prices, while this assumption has clearly been questioned. ${ }^{101}$ Moreover, BTAs in respect of cascade taxes and taxes occultes are also based, in practice, on averaging. ${ }^{102}$ In the case of cascade taxes, the tax imposed on imported products has to be determined taking into account the presumed effects of the various taxes that have been applied at each stage of the distribution chain (from the manufacturers to consumers) on the prices of final products. Since not all products are manufactured and sold to consumers following the same distribution chain, similar products may be subject to different tax burdens (the longer the distribution chain, the heavier the tax burden is likely to be). In other words, averaging characterises BTAs imposed on imported products in respect of cascade taxes: the tax rate imposed on imported products is supposed to represent the average tax rate supported by domestic products. ${ }^{103}$ Similarly, the effect of taxes occultes is necessarily determined by means of averaging since such taxes are supposed to be 'hidden' in domestic products' prices.

\footnotetext{
97 OECD 1968 Report, supra n. 50, para. 158.

98 See GATT 1970 Report, supra n. 59.

99 GATT, L/3272, supra n. 88, paras. 46-47; OECD 1968 Report, supra n. 50, para. 171 .

100 OECD 1968 Report, supra n. 50, para. 171. See also para. 151.

101 In that sense, this passage of the report appears to be in contradiction with the parts that call into question the tax shifting of consumption taxes.

102 OECD 1968 Report, supra n. 50, para. 107.

103 Ibid., para. 62:
}

It is normal practice among the cascade countries to charge imported goods with a tax at the same rate as that imposed on the sale of similar homeproduced goods by a domestic manufacturer to wholesaler, and on certain products to charge in addition a surcharge to cover tax borne on the home market before goods have reached the manufacturers (emphasis added). 
As to the eligibility of non-fiscal policies, only the OECD report tackles the question, summarising the issue as follows:

since trade between countries may be affected by various non-fiscal factors such as varying minimum wage laws, social welfare schemes, GNP per capita and even natural resources, there is no reason why distortions arising from fiscal differences should be singled out for neutralisation. Against this it may be argued that the effect of consumption taxes on prices of individual imports and exports is likely to be considerably greater than these other factors. Moreover, the choice between making and not making border adjustments for taxes is not a choice between doing something and doing nothing, but a choice between applying the destination and the origin principle. On the other hand, the choice between making border adjustments or not making border adjustments for non-fiscal factors is a choice between doing something and doing nothing (emphasis added). ${ }^{104}$

The OECD report seems to imply that a difference should be made between fiscal and non-fiscal factors for two reasons: on the one hand, the effect of fiscal factors (e.g. consumption taxes) on prices is much greater. On the other hand, taxation must be based on the destination or the origin principle, which is not the case for non-fiscal factors and policies. This last argument is not convincing: the choice between the destination and the origin principle can also be understood as a choice between 'doing something and doing nothing'. When the legislator chooses the destination principle, it can be interpreted as the expression of his choice to 'do something', namely to adopt BTAs. Conversely, when the legislator chooses the origin principle, it can be understood as the expression of his choice to 'do nothing' since he refrains from adopting BTAs.

\subsection{Problems in relation to developing countries Only the GATT} Working Party report touches upon the issue of developing countries in relation to BTAs, which can be explained by the presence of developing countries in GATT contracting parties. ${ }^{105}$ Hence, the GATT report examines BTAs applied to "products of interest to developing countries'.106

104 OECD 1968 Report, supra n. 50, para. 127.

105 See GATT, L/3272, supra n. 88, paras. 70-81; GATT, Working Party on Border Tax Adjustments, Meeting of 6-8 July 1970, Note by the Secretariat, 25 August 1970, L/3431, 4-5.

106 GATT 1970 Report, supra n. 59, paras. 28-38. 
Three main issues were put forward by developing countries. First, developing countries argued to disallow adjustments in respect of 'products which were not domestically produced by developed countries'. ${ }^{107}$ In their opinion, existing adjustment practices were not justified in light of the argument of trade neutrality given that no tax shifting had to be compensated in the absence of domestic products. ${ }^{108}$ According to some developed countries, the fact that a good was not produced domestically was not a 'realistic' criterion: revenue considerations should also be taken into account. ${ }^{109}$ Moreover, it was argued that GATT provisions could not be understood as prohibiting BTAs in respect of "products which were not domestically produced' because such an interpretation would be disadvantageous for developing countries, the fiscal revenue of which was for a large part based on non-domestically produced goods. ${ }^{110}$ Second, questions arose as to the compatibility of changes in tax structures in developed countries with GATT Article XXXVII, which requires developed contracting parties to "refrain from introducing new fiscal measures' on imports from less-developed contracting parties. ${ }^{111}$ The third issue pertained to specific taxes that were deemed discriminatory by some developing countries (e.g. taxes on tea or on some tropical products). ${ }^{12}$ According to some developed countries, these taxes were, however, to be explained by 'special health or revenue reasons'. ${ }^{113}$

\subsubsection{National and Regional Views on BTAs}

Countries did not only discuss the topic of BTAs at the OECD and GATT levels. BTAs were also discussed at the national and regional levels. National and regional views on BTAs highlight the diversity of political opinions surrounding the topic. Legal proposals and reforms in the US and the EU also illustrate the inconsistencies that exist between states' practices and the political views that they defend in international fora such as the OECD and the GATT.

\footnotetext{
107 GATT, L/3272, supra n. 88, para. 72.

108 Ibid.

109 GATT 1970 Report, supra n. 59, para. 31.

110 GATT, L/3272, supra n. 88, para. 76.

111 Ibid., paras. $73 \& 78$.

112 GATT 1970 Report, supra n. 59, paras. 35-37. See also GATT, L/3272, supra n. 88 , para. 80.

113 GATT 1970 Report, supra n. 59, paras. 36-37.
} 


\subsubsection{US views on BTAs}

As already mentioned, the US considers that its economy suffers from the fact that other countries rely heavily on BTAs while it does not make a similar use of the BTA mechanism. The main argument of the US is that its tax system does not contain any taxes that are comparable to the EU VAT system, which is a direct application of the BTA mechanism. In addition to US efforts to adapt GATT/WTO rules on BTAs at the international level, proposals have been made to modify the US tax system. ${ }^{114}$

A first proposal is to adapt the current BTA system by extending it to direct taxes in relation to export-oriented companies. ${ }^{115}$ One of the arguments put forward by the US is that "under the theory used to justify the GATT border tax adjustment rules, direct taxes were not considered to be borne by goods and were held to have no price effect'. ${ }^{116}$ In other words, the deferral of direct taxes in relation to exports should have no effect on prices and should consequently not be assimilated to a subsidy. ${ }^{117}$ This proposal is however likely to be considered contrary to WTO law, following the reasoning that was held in the case Domestic International Sales Corporation Statute (DISC). ${ }^{118}$ In this case, the US tax system allowing the deferral of a part of the profits of export-oriented domestic corporations was considered a tax subsidy prohibited under GATT Article XVI. ${ }^{119}$ The US subsequently introduced new measures.

114 Rosendahl, supra n. 34, 116-129; Robert F. van Brederode, 'The Metamorphosis of US Corporate Income Tax into a Value Added Income Tax' (2008) 19(4) International VAT Monitor 266. See also US, Hearings before the Committee on Ways and Means, House of Representatives, 'Replacing the Federal Income Tax', Impact on International Competitiveness of Replacing the Federal Income Tax (18 July 1996) \& Impact of Replacing the Federal Income Tax on Manufacturing and Energy and Natural Resources (31 July 1996), 104th Congress, 2nd Session, Serial 104-68.

115 van Brederode, supra n. 114, 268.

116 GATT, Panel Report, United States Tax Legislation (DISC), 12 November 1976, L/4422, BISD 23S/98 (US - DISC), para. 58.

117 Ibid.

118 On the relationship between the DISC legislation and BTAs, see OECD, Fiscal Committee, Note on Discussion of the DISC (Domestic International Sales Corporation). Proposal at the 35th Session of the Fiscal Committee, Paris, 12 June 1970, DAF/EC/70.7, 3, at paras. 5-6. See also Sidney Weintraub, 'Border Tax Adjustments and the GATT' (1964-1965) 17 Tax Executive 304, 312.

119 GATT, Panel Report, US - DISC. See Gary Clyde Hufbauer, 'The Foreign Sales Corporation Drama: Reaching the Last Act?' (2002) International Economics Policy Briefs 1, 3 et al. This case is analysed in more detail in Chapter 5 . 
They were, however, also rejected on the ground that they were export subsidies contrary to GATT/WTO law. ${ }^{120}$

A second proposal is to adopt VAT in the US. Though the US relies on a system of retail sales taxes at the subnational level, it is one of the only countries not to have introduced any VAT system so far. ${ }^{121}$ One of the arguments in favour of the introduction of a federal-wide VAT system is directly related to the favourable trade effects that are expected to derive from VAT systems. ${ }^{122}$ Many academics and researchers have discussed the case for the adoption of VAT in the US, without reaching a consensus on whether such change would be trade beneficial or not. ${ }^{123}$ In 2005 an Advisory Panel - appointed by George W. Bush in order to propose a reform of the Federal Internal Revenue Code - studied the case for an American VAT and the case for a National Retail Sales Tax. ${ }^{124}$ The panel

120 See the FSC and ETI cases (Chapter 5). See Hufbauer, supra n. 119; van Brederode, supra n. 114, 272-274.

121 In contrast to most countries, the US does not rely on VAT. In the US, general turnover taxes are retail sales tax (OECD, OECD Consumption Tax Trends 2012, VAT/GST and Excise Rates, Trends and Administration Issues, Annex 2, 216-217). See also Alan Schenk, 'Value Added Tax: Does this Consumption Tax Have a Place in the Federal Tax System?' (1987) 7(2) Virginia Tax Review 207, 209. The US system of sales taxes is further discussed in Chapter 3.

122 See Joseph J. Thorndike, 'Early Proposals for an American VAT' (2009) Tax Analysts. See also Stewart, Salonen \& McDonough, supra n. 11, 117 and 127-132; van Brederode, supra n. 114, 268-269.

123 William G. Gale \& Benjamin H. Harris, 'Proposal 10: Creating an American Value-Added Tax' (2013) The Hamilton Project, Brookings Institution 1; Gilbert E. Metcalf, 'Life Cycle versus Annual Perspectives on the Incidence of a Value Added Tax', in: James M Poterba (ed.), Tax Policy and the Economy (MIT Press 1994, Vol. 8); Rosendahl, supra n. 34, 127; Eric Toder, Jim Nunns \& Joseph Rosenberg, 'Using a VAT to Reform the Income Tax' (2012) Tax Policy Center, The PEW. See also US Congress, 'Effects of Adopting a Value-Added Tax' (1992) Congressional Budget Office Study.

124 US, President's Advisory Panel on Federal Tax Reform, Final Report, chapter 8 (Value-added tax) \& chapter 9 (National Retail Sales Tax), 1 November 2005. See US, Executive Order 13369, President's Advisory panel on Federal Tax Reform, 7 January 2005. See also James J. Nedumpara, 'Lessons Learned from DISC/FSC/ETI Disputes: Reshaping the Quest Towards a GATT/WTO Friendly Corporate Tax Reform in the United States' (2011) O.P. Jindal Global University, Research Paper No. 10. 
came to the conclusion that none of these two options were free of concerns. ${ }^{125}$

A recurrent proposal, introduced in the Congress at every session since 1999, is to adopt a federal sales tax while repealing the income taxes, payroll taxes, estate and gift taxes (the so-called 'Fair Tax Act'). ${ }^{126}$ One of the objectives, though not clearly mentioned, is to allow the US to benefit from BTAs. ${ }^{127}$

A third proposal is to establish fiscal measures similar to BTAs so as to compensate US producers. ${ }^{128}$ The idea is that the US should adopt BTAs on 'imports coming from and exports going to all those countries which themselves now practice a system of border adjustments'. ${ }^{129}$ Specific

125 US, President's Advisory Panel on Federal Tax Reform, Final Report, chapter 8 (value-added tax) \& chapter 9 (National Retail Sales Tax), 1 November 2005.

126 One of the last proposals is the following: US, H.R. 25, FairTax Act of 2017, 115th Congress, 1 March 2017. See also Gary Clyde Hufbauer \& Paul L.E. Grieco, 'Reforming the US Corporate Tax' (2005) Peterson Institute for International Economics; Dan R. Mastromarco, 'U.S. International Tax Reform? Define "Reform" for Me' (2006) 43(6) Tax Notes International 481; Robert F. van Brederode, 'Towards a Federal Sales Tax in the United States?' (2008) International VAT Monitor 114.

127 Walter Hellerstein, 'Recent Developments in US Subnational State Taxation with International Implications' (2008) 62(2) IBFD Bulletin 77, 85-86; Mastromarco, supra n. 126, 484; N.A, 'State Sales Tax Reform in the United States: The Streamlined Sales Tax Project' (2005) 59(5) IBFD Bulletin for International Taxation 176-181.

128 See e.g., G.N. Carlson, G.C. Hufbauer \& M.B. Krauss, 'Destination Principle Border Tax Adjustments for the Corporate Income and Social Security Taxes’ OTA Paper 20, November 1976.

129 See US, Minutes of Meeting of the Cabinet Committee on Balance of Payments, 21 December 1967, US Department of State, Foreign Relations, 1964-1968, Vol. VIII, International Monetary and Trade Policy (Document 161); Telegram from the President's Special Assistant (Califano) to president Johnson in Thailand, 22 December 1967, US Department of State, Foreign Relations, 1964-1968, Vol. VIII, International Monetary and Trade Policy (Document 162); Analytical Summary and Issues for Decision Prepared by the National Security Council Staff, NSC Meeting, 9 April 1969, US Department of State, Foreign Relations, 1969-1976, Vol. IV, Foreign Assistance, International Development, Trade Policies, 1969-1972 (Document 192), <http://www.state.goc/r/pa/ho/frus/ nixon/iv/15576.htlm> (accessed 8 February 2014), Robert F. van Brederode, Systems of General Sales Taxation: Theory, Policy and Practice (Kluwer Law International 2009), 211. 
provisions could be introduced in order not to tax imports from lessdeveloped countries or from certain industrial sectors. ${ }^{130}$ In recent years, proposals have been brought to the US Congress under the title 'Border Tax Equity Act'. ${ }^{131}$ According to Pascrell, who introduced one of these proposals: '[The Border Tax Equity Act] is geared to fight a value-added tax, which would be imposed by foreign nations on American-made products. The Border Tax Equity Act stands up against foreign export subsidies and trade barriers that offshore U.S. jobs. ${ }^{132}$ The proposal in the 2016 Ryan tax reform plan ('A Better Way') to introduce a 'destination-basis tax system' allowing to exempt exports and tax imports goes into the same direction in support of a 'pro-America approach for Global Competitiveness'. ${ }^{133}$ So far, such proposals have not been passed into law. In any case, they would likely be considered a violation of WTO law. ${ }^{134}$

\subsubsection{The EU's views on BTAs}

In the EU the discussion focused on very different aspects from the ones under discussion in the US. ${ }^{135}$ As soon as in the 1950s, France, Italy, Germany, Belgium, Luxembourg and the Netherlands started to discuss

130 See US, Telegram from the President's Special Assistant (Califano) to President Johnson in Thailand, 22 December 1967, US Department of State, Foreign Relations, 1964-1968, Vol. VIII, International Monetary and Trade Policy (Document 162).

131 US, H.R. 6183, Border Tax Equity Act of 2016, 114th Congress, 27 September 2016; US, H.R. 2600, Border Tax Equity Act of 2007, 110th Congress, 6 June 2006; US, H.R. 2927, The Border Tax Equity Act, 111th Congress, 17 June 2009; van Brederode, supra n. 129, 213-214.

132 US, H.R. 2927, The Border Tax Equity Act, 111th Congress, 17 June 2009, Floor Speech, Bill Pascrell, Jr., Public Statement, 5 May 2010.

133 Majority Members of House Committee on Ways and Means, A Better Way: Our Vision for a Confident America, 24 June 2016, 27, available at <http://abetterway.speaker.gov/_assets/pdf/ABetterWay-Tax-PolicyPaper.pdf >: 'This Blueprint eliminates the existing self-imposed export penalty and import subsidy by moving to a destination-basis system'.

134 See van Brederode, supra n. 114, 270. See also the Zenith Case: US. Supreme Court, Zenith Radio Corporation v. United States, 437 US 443 (1978); Joseph M. Bracken, 'Zenith Radio Corp. V. United States: Countervailing Duty Application to Nonexcessive Remission of Indirect Taxes' (1979) 4(2) Maryland Journal of International Law 221; Robert Dziubla, 'Zenith Radio Corp v. United States: The Demise of Congressionally Mandated Countervailing Duties' (1979) 1 Northwestern Journal of International Law \& Business 318.

135 For this section, European developments are referred to as developments in the 'European Union' (EU). Though it is true that the EU did not exist before 
the effects of BTAs in the case of intra-Community trade (i.e. trade between Member States) and the possibilities of harmonisation in the area of indirect taxes. Against this background, EU reports analysed the differences in tax systems between Member States, including the economic effect of destination-based tax systems. These reports are interesting sources of information as to EU views regarding BTAs applied between Member States. They also allow highlighting the weaknesses and inconsistencies of BTAs' theoretical basis developed at the OECD and GATT levels.

In 1953, the High Authority of the European Coal and Steel Community requested a Committee of Experts to analyse the differences in term of economic effects of destination-based or origin-based turnover taxes. ${ }^{136}$ The results reached by the Committee of Experts are summarised in the Tinbergen report, named after the Committee Chairman. The report assesses the economic effects of tax systems based on the origin and destination principles, distinguishing between taxes on specific commodities, general indirect taxes and direct taxes. The report concludes that direct taxes are generally based on the origin principle while indirect taxes usually follow the destination principle. ${ }^{137}$ The report nevertheless notes that the opposite could - in theory - also be possible. Direct tax systems could be based on the destination principle understood here in the sense that imports are taxed and exports are relieved from taxation - while general turnover taxes could follow the origin principle:

It is, perhaps, of some theoretical interest ... to note that, if one particular industry were made to pay a special high income tax, strictly speaking the country ought to give a 'refund' on all products of that industry which were exported to compensate for the specially high tax, and also to impose a compensating duty on imports of such products. The calculation of the amounts would, of course, be extremely difficult. ${ }^{138}$

1993, the term 'EU' is used as a generic term to refer to the former European Economic Community and the EU of today.

136 European Coal and Steel Community, High Authority, Report on the problems raised by the different turnover tax systems applied within the common market, report prepared by the Committee of experts set up under order No. 1-53 of the High Authority, 5 March 1953, available at <http://aei.pitt.edu/34921/1/ A1064.pdf $>$ (accessed 13 November 2015), 7.

137 Ibid., 37.

138 Ibid. See also p. 24. 
This observation of the Tinbergen report highlights that there may be different understandings of the destination principle: the view expressed in the Tinbergen report clearly does not correspond to the one of the OECD 1968 report, where direct taxes are associated with the origin principle.

Some years later, the Commission of the European Economic Community appointed three working groups and a Fiscal and Financial Committee to examine issues in relation to tax harmonisation in the European Economic Community. ${ }^{139}$

The first working group was asked to examine the possibilities for harmonisation of turnover taxes, including the removal of tax frontiers, understood as the 'removal of physical inspection at the internal political frontiers' as well as the 'removal of compensatory regulations on imports and exports between Member States'. ${ }^{140}$ The first working group also dealt with the question of fiscal frontiers from an international viewpoint. The report considered BTAs to be necessary in guaranteeing the nondiscriminatory application of turnover taxes, meaning that taxes should have 'no influence on the price structure of goods exported' and that imported goods should be 'taxed to the same extent as similar goods which are produced within the country'. ${ }^{141}$

The task of the Fiscal and Financial Committee was to analyse the disparities in tax systems between member countries in an attempt to determine the extent to which differences between tax systems might be eliminated. Against this background, one important part of the Committee report is dedicated to the analysis of the origin and destination principles. ${ }^{142}$ First, the report notes that the fact that the destination principle does not characterise 'personal income, company and wealth taxes' does not mean that direct taxes are based on the origin principle. ${ }^{143}$ According to the report, the relevant distinctions to be made regarding these taxes are based on the concepts of domicile/establishment, source

139 See European Commission, EEC Report on Tax Harmonization, The Report of the Fiscal and Financial Committee (Neumark Report) and the Reports of the Sub-Groups A, B and C, unofficial translation by H. Thurston (IBFD 1963).

140 Ibid., 13.

141 Ibid., 24, 38, 74. See Charles E. McLure, 'EU and US Sales Taxes in the Digital Age: A Comparative Analysis' (2002) 56(4) IBFD Bulletin 135, 145 : '... this system is called the "restricted origin system"".

142 See European Commission, EEC Report on Tax Harmonization, supra n. 139,145 .

143 Ibid. 
and situs. ${ }^{144}$ Second, the report explains that the principle of destination (and its application through BTAs between Member States) does not allow eliminating tax frontiers. On the one hand, 'these frontiers exist because of the fact that a good crossing them requires inspection and measures which are necessary because exports are subject to exemptions or refunds, and imports to a compensatory tax'. ${ }^{145}$ On the other hand, the report highlights practical problems in relation to BTAs, in particular the difficulty of ensuring that the exemptions on exports and the duties on importations are of the same amounts as domestic taxes. Finally, the report acknowledges the criticisms often used by the US against BTAs, namely the potential discrimination created by BTAs vis-à-vis direct taxes:

Compensation of disparities of tax burdens does not ..., in fact exclude protectionist use of refunds and compensatory taxes, given that in practice this compensation shows often deficiencies. There would occur other disadvantages in the form of disturbances of competition to the extent that it would happen that taxes affecting the formation of income are shifted on, at least partially, that is to say, lead to increase in prices. ${ }^{146}$

Given these difficulties, the report examines the possibility of adopting the origin-based principle for indirect taxes at the EU level. The report concludes that such possibility is not feasible as far as excise duties are concerned due to the important diversity in excise duties between Member States. ${ }^{147}$ Regarding turnover taxes, the report concludes that the adoption of origin-based turnover taxes is limited by two conditions: first, differences in tax rates should be 'very small' and second, Member States should have similar systems of exemptions and allowances. ${ }^{148}$ In addition to these two conditions, the destination principle should remain applicable in relation to trade with third countries. ${ }^{149}$

Overall, the reports of the working group and the Fiscal and Financial Committee suggest replacing cascade tax systems by VAT. ${ }^{150}$ Hence,

144 Ibid., 146. On this point, see Chapter 5, Section 5.2.1.1.1.2.

145 Ibid., 146 ('except in the case of a tax at the retail trade stage').

146 See European Commission, EEC Report on Tax Harmonization, supra n. $139,147$.

147 Ibid., 148.

148 Ibid., 148.

149 Ibid., 149. Note that the translation of the report is not fully correct at page 149 .

150 Ben J. M. Terra \& Peter J. Wattel, European Tax Law (Wolters Kluwer 2012), 168. 
following these reports, two Directives on VAT were adopted at the EU level, requiring Member States (and future members of the European Economic Community) to introduce VAT into their tax systems in place of their systems based on turnover taxes. ${ }^{151}$ Despite the discussions surrounding the possibility of evolving towards an origin-based tax system, the first two Directives maintained the destination principle not only for trade with third countries, but also in the case of trade between EU Member States. ${ }^{152}$

In the 1980s the Commission reopened the debate on the possibility of implementing the origin principle at the EU level. In 1985 the Commission issued a White Paper on the removal of physical, technical and fiscal barriers to complete the internal market. As to the removal of fiscal barriers, the White Paper concluded that limiting differences in tax levels between Member States is essential to achieve the removal of fiscal frontiers. ${ }^{153}$ Consequently, proposals were issued by the Commission in

151 Article 1 of the First Council Directive 62/227/EEC of 11 April 1967 on the harmonisation of legislation of Member States concerning turnover taxes, 14 April 1967, OJ 1301/67. See also Third Council Directive 69/463/EEC of 9 December 1969 on the harmonisation of legislation of Member States concerning turnover taxes - introduction of value added tax in Member States, 20 December 1969, OJ L320, 34; Fourth Council Directive 71/401/EEC of 20 December 1971 on the harmonization of the laws of the Member States relating to turnover taxes - Introduction of value added tax in Italy, 24 December 1971, OJ L283; Fifth Council Directive 72/250/EEC of 4 July 1972 on the harmonization of the laws of the Member States relating to turnover taxes - Introduction of value added tax in Italy, 18 July 1972, OJ L167, 18; Sixth Council Directive 77/388/EEC of 17 May 1977 on the harmonization of the laws of the Member States relating to turnover taxes - Common system of value added tax: uniform basis of assessment, 13 June 1977, OJ L145, 1; Council Directive 2006/112/EC of 28 November 2006 on the common system of value added tax, 11 December 2006, OJ L347 (hereafter, 'VAT Directive 2006/112/EC').

152 See Arts. 2(b), 7 and 10, $\$ 1$ (a) of the Second Council Directive 67/228/EEC of 11 April 1967 on the harmonisation of legislation of Member States concerning turnover taxes, Structure and procedures for application of the common system of value added tax, 11 April 1967, OJ L0228.

153 See White Paper from the Commission to the European Council, Completing the internal market, 14 June 1985, Brussels, COM(85)310 final, 45, para. 169; Global Communication from the Commission, Completion of the internal market: approximation of indirect tax rates and harmonisation of indirect tax structure, 26 August 1987, Brussels, $\operatorname{COM}(87) 320$ final/2, 6: 'The abolition of fiscal frontiers will bring with it the abolition for intra-Community trade of the existing system of relieving goods from tax at export and of imposing tax at import, as has indeed been envisaged ever since the First VAT Directive was adopted twenty years ago' (emphasis added). 
order to approximate VAT and excise duty rates. ${ }^{154}$ Moreover, the Commission proposed adopting an origin-based VAT system at the EU level, eliminating the concepts of importation and exportation for trade taking place within the Community. ${ }^{155}$ These proposals were, however, rejected by Member States, leading to new proposals from the Commission. ${ }^{156}$ In 1991 the Directive on the abolition of fiscal frontiers was adopted, introducing the origin principle for trade by 'private individuals' ${ }^{157}$ Moreover, this Directive replaced the concepts of exportation and importation by the concept of 'intra-Community supplies' and 'intra-Community acquisition'. ${ }^{158}$ According to Terra \& Wattel, 'the major difference is that from 1 January 1993, fiscal controls at internal frontiers are definitively abolished'. ${ }^{159}$ Despite the removal of fiscal controls, the destination principle remained the common practice. BTAs have not been eliminated, only their administration has been changed. ${ }^{160}$

Parallel to the harmonisation of VAT at the EU level, the Commission proposed to harmonise 'consumer taxes other than VAT', in particular excise duties. ${ }^{161}$ According to the Commission, the harmonisation of

154 See Terra \& Wattel, supra n. 150, 181, footnote 33.

155 Commission of the European Communities, Completion of the internal market: approximation of indirect tax rates and harmonization of indirect tax structure. Global Communication from the Commission, 26 August 1987, Brussels, $\operatorname{COM}(87) 320$ final/2, 4, points $6 \& 8$.

156 Communication from the Commission to the Council and to the European Parliament, Completion of the Internal market and Approximation of Indirect Taxes, 14 June 1989, Brussels, COM(89)260 final.

157 Terra \& Wattel, supra n. 150, 185. See also Rita de la Feria, The EU VAT System and the Internal Market (IBFD 2009), 70; Council Directive 91/680/EEC of 16 December 1991 supplementing the common system of value added tax and amending Directive 77/388/EEC with a view to the abolition of fiscal frontiers, 31 December 1991, OJ L376, 1.

158 Article 28a, page 5 et al. of Directive 91/680/EEC. See also de la Feria, supra n. 157, 71: 'the substitution of concepts appears to be more symbolic than substantive, and thus more of a linguistic change than a conceptual one'.

159 Terra \& Wattel, supra n. 150, 186 ('The taxable event, i.e. the intraCommunity acquisition, must be reported on the internal VAT return rather than to customs officials at the borders').

160 de la Feria, supra n. 157, 70. See also European Commission, Green Paper, On the future of VAT. Towards a simpler, more robust and efficient VAT system, 1 December 2010, Brussels, COM(2010)695 final, 7.

161 Commission of the European Communities, Proposed Council Directives on excise duties and indirect taxes, other than value added tax, which are levied directly or indirectly on the consumption of products, 23 February 1972, $\operatorname{COM}(72) 225$ final. 
excise duty rates was 'essential in order to abolish compensatory measures (taxes on imports and tax rebates on exports and related checks and controls) at present being applied at borders' ${ }^{162}$ In other words, the proposal was to abolish tax frontiers in intra-Community trade, not only for VAT, but also for other indirect taxes. ${ }^{163}$ The first attempts by the Commission to harmonise excise duties were, however, not successful in the 1970s. The first EU Directives on excise duties were adopted in 1992. ${ }^{164}$

The analysis of the discussions that took place at the EU level against the background of the harmonisation process highlights that different opinions have been expressed on BTAs within the EU. On the one hand, Member States have intended to abolish internal borders, including tax barriers, on products traded within the EU. This project has been supported by expert reports putting forward innovative views on BTAs (such as the idea that direct taxes could also be border adjusted). On the other hand, at the international level, EU Member States - unlike the US - have not called into question the economic relevance of BTAs.

\subsection{BTAs' MAIN THEORETICAL FOUNDATIONS}

BTAs' economic and political history highlights the diversity of opinion surrounding BTAs, in particular regarding BTAs' economic theoretical foundation and taxes' eligibility for BTAs. BTAs' economic and political history also informs the two main rationales behind BTAs. While Ricardo's foundation for BTAs was the theory of comparative advantage, the OECD and the GATT introduced - based on countries' political views on BTAs - a new theoretical rationale: the theory of absolute advantage. ${ }^{165}$

162 Commission of the European Communities, Proposed Council Directives on excise duties and indirect taxes, other than value added tax, which are levied directly or indirectly on the consumption of products, 23 February 1972, $\operatorname{COM}(72) 225$ final, explanatory note, 6.

163 See Arts. 4 and 6 of the Proposed Council Directive on excise duties and indirect taxes, other than value added tax, which are levied directly or indirectly on the consumption of products, 23 February 1972, COM(72)225 final.

164 See i.a. Council Directive 92/12/EEC of 25 February 1992 on the general arrangements for products subject to excise duty and the holding, movement and monitoring of such products, 23 March 1992, OJ L76, 1 (later amended and replaced in 2008 by Directive 2008/118/EC).

165 See e.g. the confusing use of concepts in the dispute US - FSC: references were made to the concept of comparative advantage in WTO, Panel 
Both the OECD 1968 and GATT 1970 reports provide for arguments in favour of BTAs' economic relevance, which reflects a shift in BTAs' rationale in comparison to the theory of comparative advantage. The two reports base the eligibility of taxes for BTAs on the criterion of tax shifting, regardless of whether the tax affects the relative value of products or not. The need for BTAs is explained by reference to the objective of avoiding the distortion of trade flows because of the impact of domestic consumption taxes on absolute prices. From this perspective, the two reports propose an alternative theoretical foundation for BTAs, which is closer to Smith's theory of absolute advantage than to Ricardo's

\section{BOX 1.1 RICARDIAN THEORETICAL FOUNDATION FOR BTAs}

I. Optimal trade takes place when countries' production is based on the theory of comparative advantage, meaning that production takes place where relative production costs are the lowest.

II. Comparative advantages arise out of differences in 'climate, skill, machinery'.

III. The location of production and the specialisation of country should not be distorted by other elements than 'climate, skill, machinery'.

IV. Specific taxes are shifted into price and distort relative production costs. Conversely, general taxes do not distort the relative value of goods.

V. Adjustments are needed to neutralise the potential distortions derived from the adoption of specific taxes. Without BTAs, it is preferable for countries not to adopt specific consumption taxes.

Points III and IV make it clear that the theory relies on the assumption that specific taxes distort the relative value of goods. Moreover, the main assumption of the theory is point I: 'optimal trade is conditioned by the theory of comparative advantage'.

The fact that taxation is aimed at raising public revenue that could be used to give a competitive advantage to enterprises (for example when tax revenue is used to improve transport services) does not put into question the arguments in favour of BTAs. Indeed, competitive advantages deriving from the use of tax revenue benefit to all industries (in contrast to specific taxes that only apply to a limited number of industries). Therefore, no trade distortion takes place.

Report, United States - Tax Treatment for 'Foreign Sales Corporations', 8 October 1999, WT/DS108/R (US - FSC), para. 4.1188 and to the concept of competitive advantages in the oral statements of the parties in WTO, Panel Report, United States - Tax Treatment for 'Foreign Sales Corporations', Recourse to Article 21.5 of the DSU by the European Communities, 20 August, WT/DS108/RW (e.g. para. 20 of the US statement in Annex). 
theory on the comparative advantage. This alternative political theoretical foundation for BTAs, as well as Ricardo's theory, are summarised in Boxes 1.1 (p. 45) and 1.2.

\section{BOX 1.2 ALTERNATIVE POLITICAL THEORETICAL FOUNDATION FOR BTAS (THE THEORY OF ABSOLUTE ADVANTAGE)}

I. Optimal trade takes place when countries' production is defined by the absolute advantage they have in producing certain goods (due to differences in absolute production costs).

II. Indirect taxes affect absolute production costs of goods (economic assumption): they are shifted into products prices.

III. For this reason (II), countries are discouraged from adopting indirect taxes.

IV. Therefore, to neutralise the effect on trade of countries' tax systems, BTAs are needed to preserve countries' possibility to adopt indirect taxes.

V. Against the background of the removal of tariff barriers, GATT provisions on BTAs are necessary in order not to excessively limit member countries' tax sovereignty and to allow them to freely adopt indirect taxes.

Points II and IV make it clear that the theory relies on the assumption that indirect taxes are shifted into prices. Moreover, the main assumption of the theory is point I: 'optimal trade is conditioned by the theory of absolute advantage'. The fact that point I under this theory differs from Ricardo's main assumption based on the theory of comparative advantage makes it clear that the concept of trade neutrality can be used to refer to different assumptions. According to Ricardo, trade neutrality is guaranteed when trade takes place according to the theory of comparative advantage. Under this alternative theory, trade neutrality means that trade takes place in accordance with the theory of absolute advantage. Finally, an important assumption of this alternative model is that a country is better off when its exports are substantial: the welfare of a country is linked with its production level (if this were not true, the fact that taxes are shifted into price - which consequently would lower the production level would not be an issue).

If the justification under point III is rejected (because it is not considered a problem that countries are discouraged to adopt indirect taxes), BTAs may still be considered necessary based on another assumption, namely that enterprises should not be disadvantaged by the tax system of the country in which they are located (the so-called 'competitiveness' argument). This assumption - which is based on a certain idea of equality between firms - is weaker than the 'tax sovereignty' assumption, which is a strong attribute of the state (OECD 1968 Report, para. 122).

In comparison to the Ricardian theory, this new theoretical framework seems to allow for BTAs in respect of any tax - and other non-fiscal measures - so long as it can be proven that the measure has been shifted into products' prices (based on point II). 


\subsection{INTERIM CONCLUSIONS}

The analysis of the economic and political history of traditional BTAs offers a better understanding of the different rationales that justify this fiscal mechanism. BTAs' rationales also play a major role in determining which environmental goals could be achieved through BTAs. As explained later (Part III), WTO law translates - to a certain extent - this definition into legal conditions. For example, it is clear from the theory of comparative advantage and the theory of absolute advantage that BTAs aim at neutralising the effects of domestic taxes on international trade. This aspect also appears in BTAs' legal framework: BTAs need to mirror internal taxes on like products. In other words, environmental BTAs should a priori only complement environmental domestic taxes to neutralise their effects on international trade. From this perspective, the main purpose of BTAs would be trade and not environmentally driven.

BTAs have been discussed not only in the context of international trade, but also in the context of national and regional tax policies. At the US level, proposals have been introduced to level the playing field between the US and other states whose tax systems rely heavily on BTAs. At the EU level, the debate has focused on a different question, namely 'how to remove BTAs in the case of intra-Community trade in order to achieve a fully integrated internal market?' The technical reports issued at the EU level to answer this question highlight the inconsistencies in the discourse on BTAs. In particular, inconsistencies appear in the understanding of the distinction between direct and indirect taxes, which is at the heart of BTAs' legal framework. Where, at the OECD and GATT levels, the exclusion of direct taxes for BTAs is partly justified by reference to the origin principle, EU reports seem to indicate that the origin and destination principles are not relevant criteria to distinguish between direct and indirect taxes. These inconsistencies will be used later in the critical analysis of BTAs' legal framework to argue against traditional interpretations of WTO law (Part III). 